\title{
Evidence for Two Pathways of Iodothyronine 5 -Deiodination in Rat Pituitary That Differ in Kinetics, Propylthiouracil Sensitivity, and Response to Hypothyroidism
}

\author{
Theo J. Visser, Michael M. Kaplan, Jack L. Leonard, and P. Reed Larsen, \\ Thyroid Diagnostic Center, Department of Medicine, Brigham and Women's \\ Hospital, Howard Hughes Medical Institute Laboratory, Harvard \\ Medical School, Boston, Massachusetts 02115
}

A B S T R A C T We have studied $5^{\prime}$-deiodination of thyroxine $\left(\mathrm{T}_{4}\right)$ and $3,3^{\prime}, 5^{\prime}$-triiodothyronine $\left(\mathrm{rT}_{3}\right)$ in rat pituitary tissue in vitro, with respect to substrate specificity, reaction kinetics, effects of 6-n-propyl-2thiouracil (PTU), and the time course of effects of thyroid hormone depletion and repletion. Removal of one phenolic iodine or both tyrosyl iodines from the $\mathrm{T}_{4}$ molecule resulted in compounds that were not deiodinated, but alterations in the alanine side chain had little effect.

5 -Deiodination of $2 \mathrm{nM} \mathrm{rT}_{3}$ by pituitary microsomes from euthyroid rats was inhibited $>90 \%$ by $1 \mathrm{mM}$ PTU, but was inhibited $<10 \%$ by $100 \mathrm{nM} \mathrm{T}_{4}$. The apparent Michaelis constant $\left(K_{m}\right)$ and maximum velocity $\left(V_{\text {max }}\right)$ for $\mathrm{rT}_{3}$ at $20 \mathrm{mM}$ dithiothreitol (DTT) were $33 \mathrm{nM}$ and $84 \mathrm{pmol} / \mathrm{mg}$ protein per $\mathrm{h}$. This reaction followed ping-pong type reaction kinetics when concentrations of DTT were varied. PTU inhibition was competitive with DTT and uncompetitive with $\mathrm{rT}_{3}$. In contrast, when pituitary microsomes from hypothyroid rats $(21 \mathrm{~d}$ postthyroidectomy) were used, deiodination of $2 \mathrm{nM} \mathrm{rT}_{3}$ was inhibited only $20 \%$ by $1 \mathrm{mM}$ PTU and up to $80 \%$ by $100 \mathrm{nM} \mathrm{T}_{4}$. At $20 \mathrm{mM}$ DTT, the apparent $K_{\mathrm{m}}$ and $V_{\text {max }}$ in hypothyroid microsomes were $4.7 \mathrm{nM} \mathrm{rT}_{3}$ and $16 \mathrm{pmol} / \mathrm{mg}$ protein per $h . T_{4}$ was a competitive inhibitor of PTU-insen-

Portions of this work have appeared in abstract form in the Program of the 62nd Annual Meeting of the Endocrine Society, Washington, DC, 1980 , p. 304, and the Program of the 64th Annual Meeting of the Endocrine Society, San Franciso, CA, 1982, p. 212.

Address correspondence to Dr. Michael M. Kaplan.

Received for publication 23 June 1982 and in revised form 6 December 1982. sitive $\mathrm{rT}_{3} 5^{\prime}$-deiodination $\left(K_{\mathrm{i}}=1.3 \mathrm{nM}\right) . \mathrm{T}_{4} 5^{\prime}$-deiodination by hypothyroid microsomes was not affected by PTU, was competitively inhibited by $\mathrm{rT}_{3}\left(K_{\mathrm{i}}, 1.7\right.$ $\mathrm{nM}$ ), and exhibited sequential type reaction kinetics with DTT as cosubstrate. When $\mathrm{T}_{4} 5^{\prime}$-deiodination was measured in euthyroid and hypothyroid microsomes, respectively, the apparent $K_{\mathrm{m}}$ and $V_{\max }$ for $\mathrm{T}_{4}$ at 20 $\mathrm{mM}$ DTT, were $0.9 \mathrm{nM}$ and $0.55 \mathrm{pmol} / \mathrm{mg}$ protein per $\mathrm{h}$ (euthyroid), and $0.8 \mathrm{nM}$ and $6.9 \mathrm{pmol} / \mathrm{mg}$ protein per $h$ (hypothyroid).

The $\mathrm{T}_{4} 5^{\prime}$-deiodination rate and the PTU-insensitive, but not total, $\mathrm{rT}_{3} 5^{\prime}$-deiodination rate (i.e. measured in the presence and the absence of $1 \mathrm{mM}$ PTU, respectively) in pituitary homogenates were significantly elevated $24 \mathrm{~h}$ after thyroidectomy. PTU-insensitive activity continued to increase until at $\geq 30 \mathrm{~d}$ after thyroidectomy it was 11 times the PTU-insensitive activity in controls. At the latter time, PTU-sensitive $\mathrm{rT}_{3} 5^{\prime}$-deiodinase activity appeared to be decreased. The increase in PTU-insensitive $\mathrm{T}_{4}$ and $\mathrm{rT}_{3} 5^{\prime}$-deiodination observed $48 \mathrm{~h}$ after thyroidectomy was prevented by replacement doses of $T_{4}$ or $T_{3}$. The PTUinsensitive activity of long term hypothyroid pituitaries was decreased by $71 \%$ and $\geq 84 \% 4 \mathrm{~h}$ after injection of 20 and $200 \mu \mathrm{g} \mathrm{T}_{3}$, respectively, with no change in PTU-sensitive $\mathrm{rT}_{3}$ deiodination.

These data show that rat pituitary tissue contains two distinct iodothyronine 5 -deiodinating pathways that differ with respect to substrate specificity, PTU sensitivity, reaction kinetics, and regulation by thyroid hormone. One of these resembles the 5 -deiodinase of liver and kidney, and predominates in euthyroid pituitary tissue in vitro. The other, also found in rat brain, predominates in hypothyroid pituitary tissue, 
is rapidly responsive to changes in thyroid hormone availability, and, as judged by previous, in vivo studies, appears to account for all the $\mathrm{T}_{3}$ produced locally in the pituitary and, thereby, $50 \%$ of the intracellular $\mathrm{T}_{3}$ in this tissue.

\section{INTRODUCTION}

The anterior pituitary gland is an important target tissue for thyroid hormone. Besides the well-documented negative feedback control of thyrotropin (TSH)' secretion, thyroid hormone stimulates growth hormone (GH) production by the rat pituitary (1). In $\mathrm{GH}_{3}$ cells, derived from rat pituitary tumor tissue, thyroid hormone modulates the rate of synthesis of at least six proteins, including GH (2). Ample evidence has been presented that these actions are initiated by the binding of 3,3',5-triiodothyronine $\left(T_{3}\right)$ to a nuclear chromatin-associated receptor (3-6). Yet, on some occasions a better correlation of serum TSH with serum thyroxine $\left(T_{4}\right)$ than with serum $T_{3}$ concentrations is observed (7). This may be explained by the finding that in rat pituitary one-half of the intracellular $T_{3}$ is derived from local $5^{\prime}$-deiodination of $\mathrm{T}_{4}$, the other half being taken up from the circulation $(8,9)$.

Conversion of $T_{4}$ to $T_{3}$ has been observed in rat pituitary fragments and homogenates (10-15), and in $\mathrm{GH}_{3}$ cells (16). Like the deiodinase activity of rat liver and kidney, this is a thiol-dependent process (12). Neither in vivo nor in vitro pituitary $T_{4}$ to $T_{3}$ conversion is affected by 6-propyl-2-thiouracil (PTU) $(9,12$, 17). In contrast, PTU is a potent inhibitor of the $5^{\prime}$ deiodination in liver and kidney (18-20). However, iopanoic acid, the cholecytographic dye containing a triiodoaminophenyl group, inhibits $T_{3}$ production in all tissues thus far examined $(7,11,12,21,22)$. With respect to both $\mathrm{TSH}$ and $\mathrm{GH}$ secretion, $\mathrm{T}_{4}$ action on the pituitary is blocked by iopanoic acid, or the similar drug ipodic acid, but not by PTU $(17,23,24)$. Pituitary $\mathrm{T}_{4}$ 5'-deiodinase activity in homogenates and tissue fragments is increased in hypothyroidism and decreased in hyperthyroidism $(11,12)$, whereas opposite changes are observed slices, homogenates, and microsomes from liver and kidney, as reviewed recently (7). $3,3^{\prime}, 5^{\prime}$-Triiodothyronine (reverse $\mathrm{T}_{3}, \mathrm{rT}_{3}$ ) is a more suitable substrate than $\mathrm{T}_{4}$ for the $5^{\prime}$-deiodinase activities of liver and kidney, judging from the higher ratio of $V_{\max }$ to $K_{\mathrm{m}}$ for $\mathrm{rT}_{3}(25,26)$. We have recently de-

\footnotetext{
' Abbreviations used in this paper: DTT, dithiothreitol; GII, growth hormone; PTU, 6- $n$-propyl-2-thiouracil; $\mathrm{rT}_{3}$, $3,3^{\prime}, 5^{\prime}$-triiodothyronine; tetrac, tetraiodothyroacetic acid; tetraprop, tetraiodothyropropionic acid; $\mathrm{T}_{3}$, triiodothyronine; $\mathrm{T}_{4}$, thyroxine; $\mathrm{TSH}$, thyrotropin; triac, 3,3',5-triiodothyroacetic acid; $3,3^{\prime}-T_{2}, 3,3^{\prime}$-diiodothyronine; $V_{\max }$, maximum velocity.
}

scribed two pathways of iodothyronine 5 '-deiodination catalyzed by rat cerebral cortical microsomes $(27,28)$. One pathway shares several properties with hepatic and renal 5'-deiodination, including sensitivity to PTU. The other pathway is not sensitive to PTU, sharing that property with $\mathrm{T}_{4} 5^{\prime}$-deiodination in rat pituitary tissue $(9,11,12,17)$. Much less is known about the deiodination of $\mathrm{rT}_{3}$ in the pituitary.

We have now examined reaction kinetics and compared the effects of PTU and thyroid status on the 5'deiodination of $\mathrm{T}_{4}$ and $\mathrm{rT}_{3}$ in rat pituitary. The results suggest two different pathways of iodothyronine $5^{\prime}$ deiodination in this tissue, with distinct biochemical and physiological characteristics.

\section{METHODS}

Animals and reagents. Male Sprague-Dawley rats, weighing 175-200 g, were obtained from Zivic-Miller Laboratories, Allison Park, PA. Thyroidectomies and sham operations were performed by us or the supplier. Pituitaries were harvested after exsanguination of the animals via the abdominal aorta under ether anesthesia. The effectiveness of the thyroidectomy (and thyroid hormone replacement) was confirmed by measurements of serum $\mathrm{T}_{4}, \mathrm{~T}_{3}$, and TSH at the time of death (29).

Levorotatory iodothyronines were used in all studies, unless otherwise specified. $\left.{ }^{125} \mathrm{I}\right] \mathrm{r} \mathrm{T}_{3}$, specific radioactivity $\simeq 625$ $\mathrm{Ci} / \mathrm{mmol}$, was obtained from New England Nuclear, Boston, MA, and was purified by paper electrophoresis within $2 \mathrm{~h}$ of its use in an assay, to remove ${ }^{125} \mathrm{I}^{-}$. Iopanoic acid was generously provided by the Sterling-Winthrop Research Institute, Rensselaer, NY. $\left[{ }^{125} \mathrm{I}\right] \mathrm{T}_{4}$, specific radioactivity $\simeq 1,750$ $\mathrm{Ci} / \mathrm{mmol}$, was prepared in this laboratory $(30)$ and purified by paper chromatography (21). 3,3',5,5'-Tetraiodothyroacetic acid (tetrac), 3,3',5-triiodothyroacetic acid (triac), $3,3^{\prime}, 5,5^{\prime}$-tetraiodothyropropionic acid (tetraprop, 3,3'-diiodothyronine $\left(3,3^{\prime}-\mathrm{T}_{2}\right), 3^{\prime}, 5^{\prime}-\mathrm{T}_{2}$ and $3^{\prime}$-iodothyronine $\left(3^{\prime}-\mathrm{T}_{1}\right)$ were also iodinated with ${ }^{125} \mathrm{I}$ in our laboratory by the chloramine T method, and purified on Sephadex G-25 in 0.01 $\mathrm{N} \mathrm{NaOH} \mathrm{(30).} \mathrm{Tracers} \mathrm{as} \mathrm{thus} \mathrm{synthesized} \mathrm{were} \mathrm{labeled} \mathrm{only}$ on the phenolic ring, at the $3^{\prime}$ or $5^{\prime}$ positions. Unlabeled $T_{4}$, $\mathrm{T}_{3}$, and analogs were obtained from Henning $\mathrm{GmbH}$, Berlin, West Germany, and $\mathrm{rT}_{3}$ from Calbiochem Behring, Inc., La Jolla, CA. Other reagents were obtained from CalbiochemBehring, the Sigma Chemical Co., St. Louis, MO, and Fisher Scientific Co., Pittsburgh, PA.

Tissue preparations. In initial characterization studies, anterior pituitaries were used, and homogenates and subfractions were prepared in $0.25 \mathrm{M}$ sucrose, $0.05 \mathrm{M}$ Tris, $\mathrm{pH} 7.5$, $100 \mathrm{mM}$ dithiothreitol (DTT). Subsequently, in homogenate studies, whole pituitaries were homogenized on ice in $80 \mathrm{vol}$ of $0.32 \mathrm{M}$ sucrose, $10 \mathrm{mM}$ Hepes ( $\mathrm{pH} 7.0$ ), containing 10 $\mathrm{mM}$ DTT. In experiments using in vivo treatments, pituitaries from each animal were homogenized separately. For microsomal preparations, whole pituitaries were collected from a group of 14 normal $150-175-g$ rats, and from a group of 10 hypothyroid rats, weighing $175-200 \mathrm{~g}$ at the time of thyroidectomy $21 \mathrm{~d}$ previously. Each pool was homogenized in $10 \mathrm{ml} 0.32 \mathrm{M}$ sucrose, $10 \mathrm{mM}$ Hepes ( $\mathrm{pH} 7.0$ ), containing $10 \mathrm{mM} \mathrm{DTT}$, and centrifuged for $10 \mathrm{~min}$ at $3,500 \mathrm{~g}$ at $4^{\circ} \mathrm{C}$. The pellets were resuspended in $10 \mathrm{ml}$ sucrose-Hepes-DTT buffer and centrifuged again under the same conditions. The 
combined supernatants were centrifuged for $60 \mathrm{~min}$ at $100,000 \mathrm{~g}$ and $4^{\circ} \mathrm{C}$. The pellets were rinsed with $0.1 \mathrm{M}$ potassium phosphate, $1 \mathrm{mM}$ EDTA (pH 7.0), containing $2 \mathrm{mM}$ DTT, and homogenized in $7.5 \mathrm{ml}$ of this buffer. $1-\mathrm{ml}$ aliquots of these suspensions were rapidly frozen in a dry ice-acetone bath and stored until use at $-20^{\circ} \mathrm{C}$. The $3,500-100,000 \mathrm{~g}$ pellets are referred to as crude microsomal fractions, but contain mitochondria as well. The protein content of the microsomal preparations from the euthyroid and hypothyroid pituitaries amounted to 0.45 and $0.50 \mathrm{mg} / \mathrm{ml}$, respectively. The protein content of the tissue preparations was measured with the dye-binding assay of Bradford (31), using ovalbumin as the standard, reagents from Bio-Rad Laboratories (Richmond, CA), and detailed procedures as specified in the instructions from Bio-Rad.

Deiodination measurements. Tissue 5'-deiodinase activities were measured by the release of radioactive iodide from $\left[{ }^{125} \mathrm{I}\right] \mathrm{T}_{4}$ or $\left.{ }^{125} \mathrm{I}\right] \mathrm{r} \mathrm{T}_{3}$ (assay $\left.\mathrm{A}\right)(26)$, or the production of radioactive $\mathrm{T}_{3}$ from [ $\left.{ }^{125} \mathrm{I}\right] \mathrm{T}_{4}$ (assay B) (21). For assay $\mathrm{A}, 50 \mu \mathrm{l}$ (22.5-25 $\mu$ g protein) of the homogenates or microsomes were mixed with $50 \mu \mathrm{l} 0.2 \mathrm{M}$ potassium phosphate, $\mathrm{pH} 7.0$, containing (with final concentrations in the reaction mixtures in parentheses) $100,000 \mathrm{cpm}$ labeled iodothyronine of varying specific activites EDTA $(1 \mathrm{mM})$ and DTT and PTU as indicated. The reaction was started by the addition of microsomes and allowed to continue for $45-120 \mathrm{~min}$ at $37^{\circ} \mathrm{C}$ in air. Tissue-free incubations served as controls. Analyses of reaction products were performed as described (21). The reaction was stopped by successive additions of $50 \mu \mathrm{l} 50 \%$ human serum containing PTU, and $350 \mu \mathrm{l}$ of cold $10 \%$ trichloroacetic acid. The acid soluble radioiodide was isolated in the unretarded fractions after chromatography of the supernatants on $1.2 \mathrm{ml}$ Dowex 50W-X8 columns (Dow Corning Corp., Midland, MI), equilibrated, and eluted with $10 \%$ acetic acid $(2 \times 1 \mathrm{ml})$. The coefficient of variation of replicate analyses was $<5 \%$.

The reductive conditions of the reaction mixture for assay A that contained both EDTA and DTT were designed to inhibit totally peroxidase-catalyzed deiodination. In fact, no $\mathrm{I}^{-}$release was observed in the absence of reduced thiols. In addition, no $\mathrm{I}^{-}$release from $\mathrm{rT}_{3}$ occurred in the presence of $20 \mathrm{~mm}$ DTT using heat-inactivated $\left(100^{\circ} \mathrm{C}\right.$ for $\left.10 \mathrm{~min}\right) \mathrm{pi}$ tuitary homogenates from hypothyroid or euthyroid rats supporting the enzymatic nature of the $5^{\prime}$-deiodination of $\mathrm{rT}_{3}$. When pituitary homogenates from hypothyroid and euthyroid rats were incubated with [ $\left.{ }^{125} \mathrm{I}\right] \mathrm{rT}_{3}$ with or without $10^{-3} \mathrm{M}$ PTU, and the products identified by paper chromatography, the $I^{-} / 3,3^{\prime} T_{2}$ ratio was not significantly different from unity (1.07). There was also no effect of PTU on this ratio (1.09) control, (1.05 PTU), and no other products were found. In addition, similar studies using pituitary microsomes from hypothyroid rats and $\left[{ }^{125} \mathrm{I}\right] \mathrm{T}_{4}$ as substrate over a broad range of fractional $T_{4}$ to $T_{3}$ conversion rates showed that the mean ratio of ${ }^{125} \mathrm{I}^{-}$to $\left[{ }^{125} \mathrm{I}\right] \mathrm{T}_{3}$ generated was $0.98, \mathrm{r}^{2}=0.99$. These results confirm that under these reaction conditions, quantitation of ${ }^{125} \mathrm{I}^{-}$release from $\left[{ }^{125} \mathrm{I}\right] \mathrm{rT} \mathrm{T}_{3}$ or $\left[{ }^{125} \mathrm{I}\right] \mathrm{T}_{4}$ is a valid measure of the rate of $5^{\prime}$-deiodination as has been reported previously for both kidney $(26)$ and cerebral cortex $(27,28)$ microsomes.

For assay B, $90 \mu \mathrm{l}(40-45 \mu \mathrm{g}$ protein) of homogenate was mixed with $10 \mu \mathrm{l} 0.25 \mathrm{M}$ sucrose, $0.05 \mathrm{M}$ Tris, $\mathrm{pH} 7.5$, containing $40,000 \mathrm{cpm}\left[{ }^{125} \mathrm{I}\right] \mathrm{T}_{4}(\simeq 0.2 \mathrm{nM})$, unlabeled $\mathrm{T}_{4}(0$ or 10 $\mathrm{nM}), \mathrm{T}_{3}(0$ or $1 \mu \mathrm{M})$ and DTT $(100 \mathrm{mM})$. Incubations were carried out for $60 \mathrm{~min}$ at $37^{\circ} \mathrm{C}$ under nitrogen. In control incubations, homogenate was replaced by buffer. The reaction was stopped by addition of $200 \mu \mathrm{l}$ ethanol and 50 $\mu \mathrm{l} 0.04 \mathrm{~N} \mathrm{NaOH}$ containing $50 \mu \mathrm{g} \cdot \mathrm{T}_{4}, 50 \mu \mathrm{g} \mathrm{T}_{3}$, and 285 $\mu \mathrm{g}$ methimazole. After centrifugation and addition of carrier $I^{-}, T_{3}$, and $T_{4}$, aliquots of the supernatants were subjected to descending paper chromatography in t-amyl alcohol/hexane/2 $\mathrm{N}$ ammonia (5:1:6). The coefficient of variation of replicate determinations was $6.5 \%$. The chromatograms were developed and counted as described (2l). Deiodination of $\left[{ }^{125} \mathrm{I}\right] 3^{\prime}-\mathrm{T}_{1}$ and $3^{\prime}, 5^{\prime}-\mathrm{T}_{2}$ was measured by paper electrophoresis $(21)$

Data analysis. Product formation was corrected for nonenzymatic deiodination and contamination of substrates by subtraction of the respective control value, which always amounts to $<1 \%\left(\mathrm{I}^{-}\right)$or $3 \%\left(\mathrm{~T}_{3}\right)$ of radioactivity added. Recovery of ${ }^{125} \mathrm{I}^{-}$through the column procedure was better than $97 \%$. A factor of 2 was applied to account for the fact that the specific radioactivity of the products was half that of the substrates, randomly labeled in the equivalent $3^{\prime}$ and $5^{\prime}$ positions. Each experimental point was determined in duplicate $\left(\mathrm{T}_{3}\right.$ by paper) or triplicate ( $\mathrm{I}^{-}$by column). In the study of the influence of thyroid status on pituitary deiodinase activities, group means were tested by analysis of variance and, if significant differences were present, individual experimental groups were compared to the controls by Dunnett's multiple $t$ test (32). In the study of the kinetics of the 5 '-deiodination by pituitary microsomes, conditions were chosen such that $<20 \%$ of the substrates were consumed during the reaction. Linear regression lines in kinetic analyses were calculated by unweighted least squares analysis. Equations for the components of nonlinear Eadie-Hofstee plots were calculated by the method of Rosenthal (33), with five iterations of the cross corrections.

\section{RESULTS}

Initial characterization of the reaction system. Assay B was used for the studies in this section. The only products other than $\mathrm{T}_{4}$ observed on the chromatograms after incubation of $T_{4}$ with pituitary homogenates or pituitary microsomes were $\mathrm{T}_{3}$ and $\mathrm{I}^{-}$, and the only products observed after incubations with $\mathrm{rT}_{3}$ were $3,3^{\prime}-\mathrm{T}_{2}$ and $\mathrm{I}^{-}$. With both substrates, the amounts of $\mathrm{I}^{-}$and the deiodinated iodothyronine did not differ significantly. Product formation, i.e. $\mathrm{T}_{3}$ and $I^{-}$from $T_{4}$ and $3,3^{\prime}-T_{2}$ and $I^{-}$from $r_{3}$, was linear with microsomal protein concentration to at least 100 $\mu \mathrm{g} / \mathrm{ml}$, and with incubation time to at least $120 \mathrm{~min}$. All subsequent experiments with microsomes were carried out within these confines.

$\mathrm{T}_{4} 5^{\prime}$-deiodinase activity was associated predominantly with the $1,000-100,000-g$ pellet of pituitary homogenates from chronically hypothyroid rats. Relative to the homogenate (defined as 1.0), the specific 5 -deiodinase activity of the low-speed pellet was found to be $0.7 \pm 0.1$ (mean $\pm S E, n=3$ ), that of the $1,000-100,000-g$ pellet ("microsomes") $2.9 \pm 0.6$, and that of the cytosol $0.3 \pm 0.1$. A dispersed enzyme preparation was obtained by treatment of the microsomes with $0.5 \%$ cholate, followed by removal of excess cholate from the nonpelletable fraction by dialysis. The specific activity of this clear preparation was $3.9 \pm 1.0$. 
The nature and the extent of the reaction of several radioiodine-labeled $\mathrm{T}_{4}$ analogs with the dispersed enzyme at $37^{\circ} \mathrm{C}, \mathrm{pH} 7.6$ and $100 \mathrm{mM}$ DTT was investigated by paper chromatography. $\mathrm{L}-\mathrm{T}_{4}, \mathrm{D}-\mathrm{T}_{4}$, tetrac, tetraprop, and $\mathrm{rT}_{3}$ were all actively deiodinated. The only products observed were the 5 -monodeiodinated compounds, i.e. $\mathrm{T}_{3}$, triac, triprop, or $3,3^{\prime}-\mathrm{T}_{2}$, and equal amounts of $\mathbf{I}^{-}$. $\mathrm{T}_{3}, 3,3^{\prime}-\mathrm{T}_{2}, 3^{\prime}, 5^{\prime}-\mathrm{T}_{2}, 3^{\prime}-\mathrm{T}_{1}$, and triac were not deiodinated to any discernable extent. The rate of deiodination by the dispersed enzyme of tracer $\left[{ }^{125} \mathrm{IJT}_{4}(\simeq 0.2 \mathrm{nM})\right.$ was inhibited $>50 \%$ by addition of $20 \mathrm{nM} \mathrm{D}^{-\mathrm{T}_{4}}$, tetrac or tetraprop. It required $500 \mathrm{nM}$ iopanoic acid to attain $50 \%$ inhibition of $\mathrm{T}_{4} 5^{\prime}$-deiodination, and the reaction was not measurably inhibited by $1 \mu \mathrm{M} \mathrm{T}, 3,3^{\prime}-\mathrm{T}_{2}, 3,5-\mathrm{T}_{2}$ or diiodotyrosine.

Using the dispersed enzyme and $100 \mathrm{mM}$ DTT, the $5^{\prime}$-deiodination of $T_{4}$ was found to obey simple saturation kinetics with an apparent $K_{\mathrm{m}}$ value of $4.3 \pm 1.0$ $\mathrm{nM}$ and $V_{\max }$ of $48 \pm 5 \mathrm{pmol} / \mathrm{mg} /$ protein per $\mathrm{h}$ (mean \pm SE, $n=4)$. However, studied under the same conditions, the kinetics of $\mathrm{rT}_{3} 5^{\prime}$-deiodination were more complex, with a nonlinear Eadie-Hofstee plot (34) that was concave upward (not shown). The results were best described by invoking two enzymatic processes with approximate $K_{\mathrm{m}}$ values of 3.1 and $152 \mathrm{nM}$, and $V_{\max }$ values of 2.1 and $26 \mathrm{pmol} / \mathrm{mg}$ protein per $\mathrm{h}$, respectively.

Kinetics of 5'-deiodination by pituitary microsomal fractions. To investigate further the possibility of more than one 5 '-deiodination reaction in the pituitary, detailed kinetic analysis of this reaction was performed using microsomes from euthyroid and hypothyroid rats as sources of enzyme and $\mathrm{rT}_{3}$ and $\mathrm{T}_{4}$ as substrates.
Stimulation of $r T_{3} 5^{\prime}$-deiodination by DTT. $5^{\prime}$ Deiodination of $\mathrm{rT}_{3}$ by euthyroid microsomes at 20 mM DTT followed simple saturation kinetics, characterized by a mean apparent $K_{\mathrm{m}}$ of $33 \mathrm{nM}$ and $V_{\max }$ of $84 \mathrm{pmol} / \mathrm{mg}$ protein per h (Table I). Both parameters were, however, greatly influenced by the DTT concentration, as illustrated in Fig. 1A. Double-reciprocal plots of the data showed parallel, downward displacements with increasing fixed concentrations of DTT, suggesting "ping-pong" type reaction kinetics (34). Apparent $K_{\mathrm{m}}$ and $V_{\max }$ values increased with the DTT concentration between 10 and $50 \mathrm{mM}$ DTT, but higher concentrations of thiol were inhibitory (see below).

Inhibition of $r T_{3}$ deiodination by PTU. The 5'deiodination of $\mathrm{rT}_{3}(2 \mathrm{nM})$ by the microsomal fraction of euthyroid pituitaries in the presence of $20 \mathrm{mM}$ DTT was progressively inhibited by the addition of increasing concentrations of PTU. Over $90 \%$ inhibition was reached with $1 \mathrm{mM}$ PTU (Fig. 2, left panel). The mode of inhibition by PTU was investigated in incubations of 10-125 nM rT ${ }_{3}$ with euthyroid microsomes and 20 $\mathrm{mM}$ DTT in the absence or the presence of 1 or $2 \mu \mathrm{M}$ of the inhibitor. Addition of PTU resulted in parallel, upward shifts of the double-reciprocal plots of $\mathrm{rT}_{3}$ deiodination (Fig. 1B), demonstrating that PTU is an uncompetitive inhibitor of this reaction.

The interaction of PTU with the cofactor, DTT, was then studied by measuring deiodination at a single $\mathrm{rT}_{3}$ concentration $(25 \mathrm{nM})$ and varying DTT $(10-125 \mathrm{mM})$ concentrations, with or without addition of 1 or $2 \mu \mathrm{M}$ PTU. Fig. 1C shows that PTU only affected the slope but not the $y$-intercept of the double-reciprocal plots,

TABLE I

Kinetic Parameters of T4 and rT3 5'-Deiodination by Rat Pituitary Microsomes

\begin{tabular}{|c|c|c|c|c|c|}
\hline Microsomes & Substrate & $\begin{array}{l}\text { PTU } \\
\text { added }\end{array}$ & $n$ & $K_{\mathrm{m}}$ & $v_{\max }$ \\
\hline & & $m M$ & & $n M$ & $\begin{array}{c}p m o l / m g \\
\text { protein per } h\end{array}$ \\
\hline \multirow[t]{2}{*}{ Euthyroid } & rT3 & - & 3 & $33(30-36)$ & $84(69-94)$ \\
\hline & $\mathrm{T} 4$ & - & 1 & 0.9 & 0.55 \\
\hline \multirow{4}{*}{$\begin{array}{l}\text { Hypothyroid } \\
\text { (21 d post- } \\
\text { thyroidectomy) }\end{array}$} & $\mathrm{rT} 3$ & - & 3 & $4.7\left(3.7^{\circ}-6.7\right)$ & $16\left(8^{\circ}-30\right)$ \\
\hline & & 1 & 2 & $2.9\left(1.6^{\circ}-4.2\right)$ & $4.7\left(3.5^{\circ}-5.9\right)$ \\
\hline & $\mathrm{T} 4$ & - & 3 & $0.6(0.55-0.7)$ & $8.3(7.2-10.2)$ \\
\hline & & 1 & 1 & 0.8 & 6.9 \\
\hline
\end{tabular}

Incubations were performed in triplicate at $\mathrm{pH} 7.0$ and $37^{\circ} \mathrm{C}$, with products quantitated by assay $A$. The DTT concentration was $20 \mathrm{mM}$ in all experiments except one, in which $15 \mathrm{mM}$ DTT was used (values marked with ${ }^{\circ}$ ), $n$, number of determinations of the kinetic parameters. For $n>1$, results are given as the mean and range of values from different experiments. 


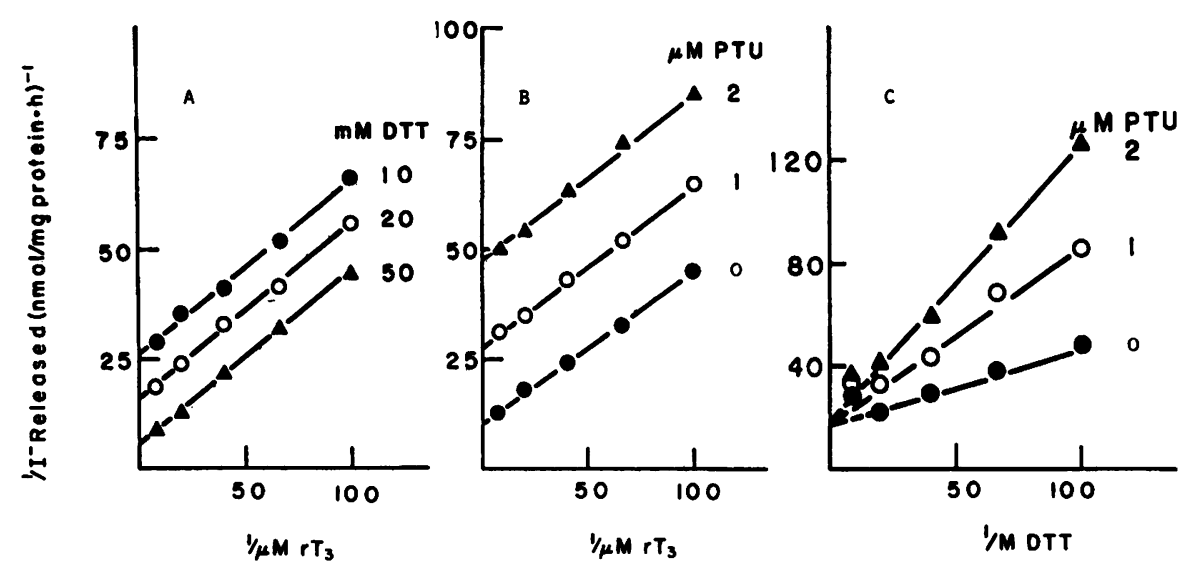

Figure 1 Double-reciprocal plots of the rate of $\mathrm{rT}_{3} 5^{\prime}$-deiodination by euthyroid rat pituitary microsomes (panel A) as a function of $\mathrm{rT}_{3}$ concentration at 10,20 , or $50 \mathrm{mM}$ DTT; (panel B) as a function of $\mathrm{rT}_{3}$ concentration at $20 \mathrm{mM}$ DTT and 0.1 or $2 \mu \mathrm{M}$ PTU; (panel C) as a function of DTT concentration at $25 \mathrm{nM} \mathrm{rT}$ and 0,1 or $2 \mu \mathrm{M}$ PTU. Points are means of triplicate determinations. Iodide release was measured by the ion-exchange assay (assay $\mathrm{A}$ ).

indicating that PTU inhibition is competitive with the cofactor. Fig. $1 \mathrm{C}$ also shows the inhibition observed at DTT concentrations $>50 \mathrm{mM}$. The intercept-replot of Fig. 1B and the slope-replot of Fig. 1C (not shown) yielded approximate $K_{i}$ values for PTU of 0.6 and 0.7 $\mu \mathrm{M}$, respectively.

In contrast to the above results with euthyroid pituitary microsomes, $1 \mathrm{mM}$ PTU caused $<20 \%$ inhibition of $\mathrm{rT}_{3} 5^{\prime}$-deiodination in microsomes from $21 \mathrm{~d}$ thyroidectomized rats (Fig. 2, left panel). These results indicated that hypothyroidism was associated with an increase in the activity of a $5^{\prime}$-deiodinase mechanism for $\mathrm{rT}_{3}$, which was PTU-insensitive. This phenomenon was explored further by evaluation of the relative sensitivities of euthyroid and hypothyroid microsomal deiodinations of $\mathrm{rT}_{3}$ to inhibition by $\mathrm{T}_{4}$.

Inhibition of $r T_{3}$ deiodination by $T_{4}$. The 5'-deiodination of $\mathrm{rT}_{3}$ by pituitary microsomes from rats thyroidectomized $21 \mathrm{~d}$ previously was characterized by a mean apparent $K_{\mathrm{m}}$ value of $4.7 \mathrm{nM}$ and $V_{\max }$ of 16 $\mathrm{pmol} / \mathrm{mg}$ protein per $\mathrm{h}$ at $20 \mathrm{mM}$ DTT (Table I). Both of these values were much lower than those for euthyroid microsomes. Nonlinear double-reciprocal plots were observed at high $(>25 \mathrm{nM}) \mathrm{rT}_{3}$ concentrations (not shown), again indicating the involvement of more than one enzymatic process. The $5^{\prime}$-deiodination of $\mathrm{rT}_{3}$ ( $2 \mathrm{nM}$ ) by these microsomes was progressively inhibited by increasing concentrations of $T_{4}$, until, with 100 $\mathrm{nM} \mathrm{T}_{4}$, a plateau was reached at $20 \%$ of the control activity (Fig. 2, right panel). Much less inhibition by $\mathrm{T}_{4}$ was observed in microsomes from euthyroid rats, with $>90 \%$ of the activity remaining in the presence of as high as $100 \mathrm{nM} \mathrm{T}_{4}$ (Fig. 2, right panel). These data demonstrate a further difference between euthy- roid and hypothyroid rats with respect to $\mathrm{rT}_{3} 5^{\prime}$-deiodination.

To elucidate the nature of the interaction between $\mathrm{rT}_{3} 5^{\prime}$-deiodination and $\mathrm{T}_{4}$, hypothyroid microsomes were reacted with 1.5-12.5 $\mathrm{nM} \mathrm{rT}_{3}$ and 0-10 $\mathrm{nM} \mathrm{T}_{4}$. Addition of $\mathrm{T}_{4}$ affected the slope but not the $\mathrm{y}$-intercept in the double-reciprocal plot, demonstrating that inhibition by $T_{4}$ was competitive with $\mathrm{rT}_{3}$ (Fig. 3). However, the increase in the slope was not propor-

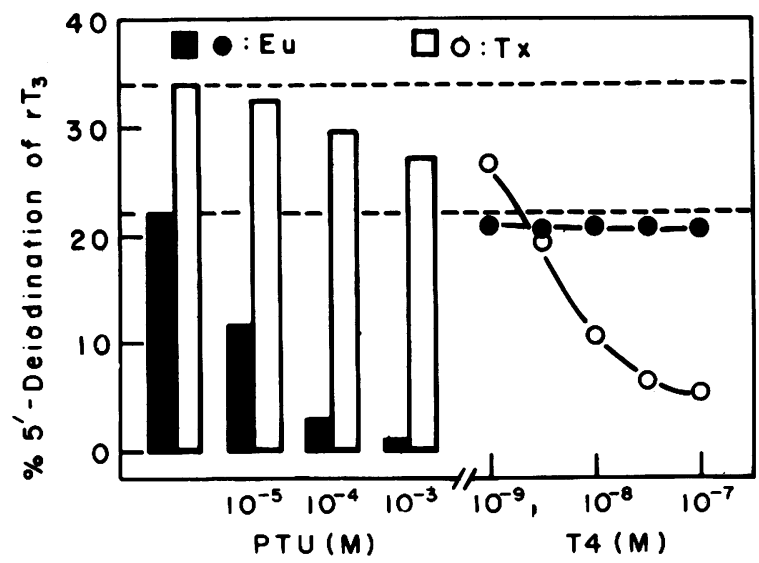

Figure 2 Effects of PTU (left panel) and $\mathrm{T}_{4}$ (right panel) on $5^{\prime}$-deiodination of $2 \mathrm{nM} \mathrm{rT}_{3}$ during 2 -h incubations with $20 \mathrm{mM}$ DTT and either $50 \mu \mathrm{g}$ euthyroid pituitary microsomes or $55 \mu \mathrm{g}$ of hypothyroid pituitary microsomes. Results are means of triplicate determinations, using assay $\mathbf{A}$. Solid symbols designate data from euthyroid microsomes, and open symbols designate data from hypothyroid microsomes. The upper broken line shows the control rate (no $\mathrm{T}_{4}$ or PTU added) for the hypothyroid preparation and the lower broken line shows the control rate for the euthyroid preparation. 


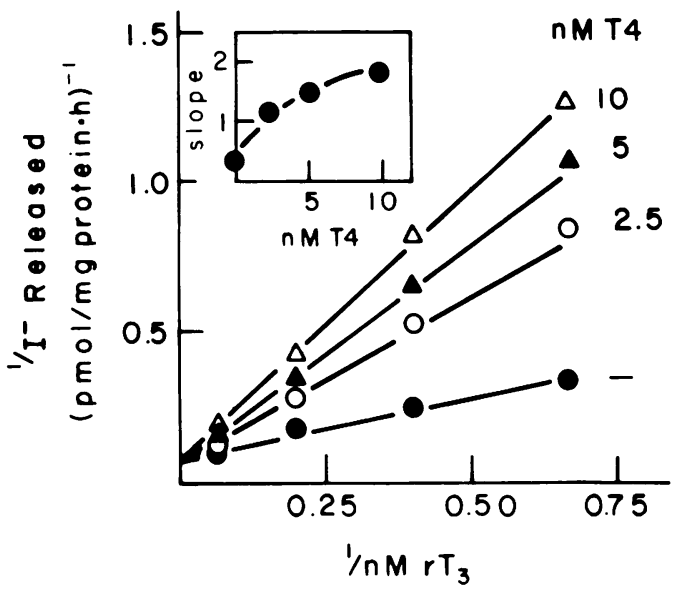

Fic:'Rt: 3 Double-reciprocal plots of the rate of $\mathrm{rT}_{3} 5^{\prime}$-deiodination by hypothyroid rat pituitary microsomes as a function of $\mathrm{rT}_{3}$ concentration in the presence of $20 \mathrm{mM}$ DTT and $0,2.5,5$, or $10 \mathrm{nM} \mathrm{T}$. Points are means of triplicate determinations, using assay $A$. Inset: Replot of slopes of the double reciprocal lines as a function of $\mathrm{T}_{4}$ concentration.

tionate to the $\mathrm{T}_{4}$ concentration, and the replot, slope vs. $\mathrm{T}_{4}$ (Fig. 3 , inset), was clearly hyperbolic, concave down. This suggested that only one of two putative pathways for the deiodination of $\mathrm{rT}_{3}$ was inhibited by $\mathrm{T}_{4}$. From the data in Fig. 2, this was thought most likely to represent inhibition of only the pathway insensitive to PTU. This hypothesis was tested in the next series of experiments.

The 5 -deiodination of $\mathrm{rT}_{3}$ by hypothyroid microsomes and $15 \mathrm{mM}$ DTT was determined in incubations containing 1.5-37.5 $\mathrm{nM} \mathrm{rT}_{3}$ and 0 or $1 \mathrm{mM}$ PTU. The presence of PTU resulted in a decrease of both the apparent $K_{\mathrm{m}}$ and the $V_{\max }$ for $\mathrm{rT}_{3}$ deiodination, i.e. 1.6 vs. $3.7 \mathrm{nM}$ and 3.5 vs. $8 \mathrm{pmol} / \mathrm{mg}$ protein per $\mathrm{h}$ (Table I). The difference between the activities measured in the absence and in the presence of PTU, i.e. PTUsensitive $\mathrm{rT}_{3} 5^{\prime}$-deiodination, also yielded a linear double-reciprocal plot, characterized by values for $K_{\mathrm{m}}$ and $V_{\max }$ of $17 \mathrm{nM} \mathrm{rT}_{3}$ and $6 \mathrm{pmol} / \mathrm{mg}$ protein per h, respectively. Similar effects of $1 \mathrm{mM}$ PTU on the parameters of $\mathrm{rT}_{3} 5^{\prime}$-deiodination were also evident at $20 \mathrm{mM}$ DTT (Table I)

The effects of increasing concentrations $(1.25-5 \mathrm{nM})$ of $\mathrm{T}_{4}$ on the PTU-insensitive deiodination of $\mathrm{rT}_{3}(1.5-$ $12.5 \mathrm{nM}$ ) by hypothyroid microsomes and $20 \mathrm{mM}$ DTT was investigated in the presence of maximally inhibiting PTU concentrations ( $1 \mathrm{mM})$. Again, inhibition by $\mathrm{T}_{4}$ was found to be competitive with $\mathrm{rT}_{3}$ but the slope of the double-reciprocal plot was now linearly dependent on the $T_{4}$ concentration (data not shown) From this slope replot an apparent $K_{\mathrm{i}}$ value of $1.3 \mathrm{nM}$ for $\mathrm{T}_{4}$ was estimated

$T_{4} 5^{\prime}$-deiodination. Deiodination of $\mathrm{T}_{4}$ by hypo- thyroid microsomes was much more extensive than that observed with euthyroid microsomes. Measurement of the kinetic parameters in the presence of 20 mM DTT revealed that although apparent $K_{\mathrm{m}}$ values were very similar $(0.6-0.9 \mathrm{nM})$ in microsomes from euthyroid and hypothyroid rats, maximal reaction rates (apparent $V_{\text {max }}$ derived from double reciprocal plots) were 16-fold higher in the hypothyroid preparation than in the euthyroid preparation, 8.3 vs. 0.55 $\mathrm{pmol} / \mathrm{mg}$ protein per $\mathrm{h}$, respectively, (Table I). Note that the higher $V_{\max }$ for $\mathrm{T}_{4} 5^{\prime}$-deiodination given in the first section of Results was determined at a fivefold higher DTT concentration, using a more enriched enzyme preparation.

The stimulation of $\mathrm{T}_{4}$ deiodination by DTT was analyzed in incubations containing $0.5-5 \mathrm{nM} \mathrm{T}_{4}, 2.5-20$ $\mathrm{mM}$ DTT, and hypothyroid pituitary microsomes. Double-reciprocal plots of deiodination rate vs. $\mathrm{T}_{4}$ concentration, each at a fixed level of DTT, intersected in a single point to the left of the vertical and close to the horizontal axis (Fig. 4). A similar set of intersecting lines was obtained by plotting reciprocals of deiodination rate vs. DTT at fixed $\mathrm{T}_{4}$ concentrations (not shown). In each case the intercept replot as a function of the fixed substrate was linear (e.g. Fig. 4, inset) providing values for the limiting Michaelis constants; $K_{\mathrm{a}}=0.7 \mathrm{nM} \mathrm{T}_{4}$, extrapolated to infinite DTT; $K_{\mathrm{b}}$ $=9 \mathrm{mM}$ DTT, extrapolated to infinite $T_{4}$; and $V_{1}$ $=13 \mathrm{pmol} / \mathrm{mg}$ protein per $\mathrm{h}$. Addition of $1 \mathrm{mM}$ PTU did not affect $\mathrm{T}_{4} 5^{\prime}$-deiodinase activity (Table I), but $\mathrm{rT}_{3}$ was found to be a competitive inhibitor of $\mathrm{T}_{4}$ conversion by hypothyroid microsomes in the presence of $20 \mathrm{mM}$ DTT (not shown), with an apparent $K_{\mathrm{i}}$ value for $\mathrm{rT}_{3}$ of $1.7 \mathrm{nM}$.

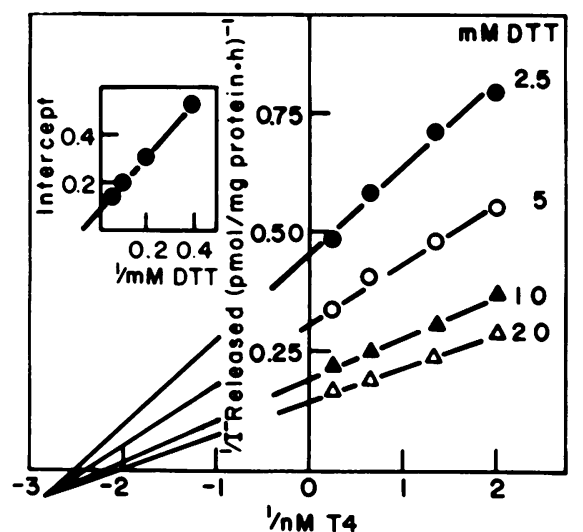

Figurt 4 Double-reciprocal plots of the rate of $\mathrm{T}_{4} 5^{\prime}$-deiodination by hypothyroid rat pituitary microsomes as a function of $\mathrm{T}_{4}$ concentrations in the presence of $2.5,5,10$, or 20 $\mathrm{mM}$ DTT. Points are means of triplicate determinations, using assay $A$. Inset: Replot of the vertical intercept of the double reciprocal lines vs. the reciprocal of the DTT concentration. 
Acute effects of changes in thyroid status on pituitary 5'-deiodinase activities. The marked qualitative and quantitative differences in $5^{\prime}$-deiodination reactions between euthyroid and hypothyroid pituitary microsomes led to studies of the time dependence of these changes after thyroidectomy. In pituitary homogenates of the sham controls, the mean $( \pm \mathrm{SE})$ deiodination rate for $\mathrm{rT}_{3}$ was $534 \pm 66(n=10) \mathrm{fmol} \mathrm{I}^{-} / \mathrm{mg}$ protein per $h$. No significant alterations were observed until $10 \mathrm{~d}$ postthyroidectomy, when the mean rate was $920 \pm 121 \mathrm{fmol} \mathrm{I}^{-} / \mathrm{mg}$ protein per h $(n=4, P<0.05)$ (Fig. 5). However, PTU-insensitive $\mathrm{rT}_{3}$ deiodination increased more rapidly. PTU-insensitive $\mathrm{rT}_{3}{ }^{5}$-deiodinase activity in the euthyroid, sham-operated controls was $84 \pm 5 \mathrm{fmol} \mathrm{I}^{-} / \mathrm{mg}$ protein per $\mathrm{h}$, representing, on the average, $16 \%$ of the total activity. PTU-insensitive activity was significantly elevated $48 \mathrm{~h}$ after thyroidectomy, $P<0.01$ (Fig. 5), and continued to increase gradually to $938 \pm 66 \mathrm{fmol} \mathrm{I}^{-} / \mathrm{mg}$ protein per $h$ in chronically ( $\geq 30 \mathrm{~d}$ after thyroidectomy) hypo-

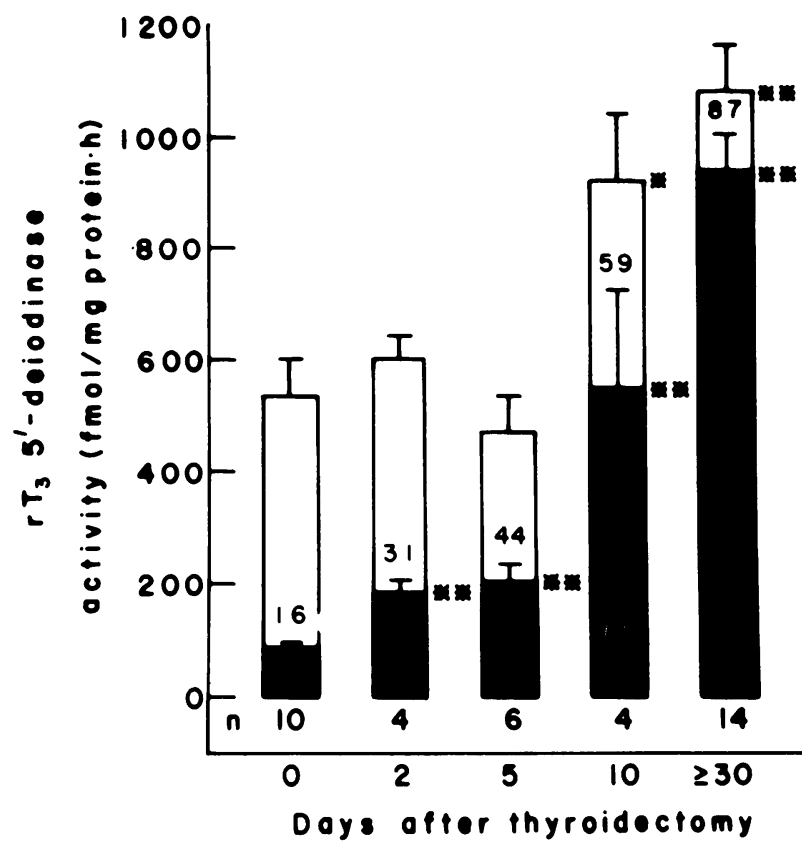

FIciure 5 The rate of $\mathrm{rT}_{3} 5^{\prime}$-deiodination in rat pituitary homogenates as a function of time after thyroidectomy. Control rates $(0$ days after thyroidectomy are pooled values from sham-operated rats killed 2,5 and $10 \mathrm{~d}$ after surgery, simultaneously with the 2-, 5-, and 10-d thyroidectomized animals. Pituitaries from each animal were homogenized separately. Rates were determined by assay A, performed in triplicate for each pituitary. Reaction mixtures contained $2 \mathrm{nM} \mathrm{rT}_{3}, 20 \mathrm{mM}$ DTT, and no PTU (total bars) or $1 \mathrm{mM}$ PTU (filled portions of bars). Numbers within the bars represent the mean rate in the presence of PTU as a percentage of that in the absence of PTU. Values are mean \pm SEM. ${ }^{\circ} P$ $<0.05$ compared to corresponding (i.e. total or PTU-insensitive) value in euthyroid controls. ${ }^{\circ} P<0.01$. thyroid rats. PTU-insensitive activity in the latter animals was $87 \%$ of the enzyme activity measured in the absence of PTU. The difference between total and PTU-insensitive $\mathrm{rT}_{3} 5^{\prime}$-deiodination, i.e. PTU-sensitive activity, was $0.45 \mathrm{pmol} / \mathrm{mg}$ protein per $\mathrm{h}$ in pituitary homogenates from the euthyroid rats, compared to only $0.14 \mathrm{pmol} / \mathrm{mg}$ protein per $\mathrm{h}$ in homogenates from chronically hypothyroid rats.

Changes in deiodination rates at still shorter times after thyroidectomy and with $T_{4}$ or $T_{3}$ repletion were then investigated using both $\mathrm{rT}_{3}$ and $\mathrm{T}_{4}$ as substrates (Table II). Production of $T_{3}$ from tracer $T_{4}(\sim 0.2 \mathrm{nM})$ was $0.22 \pm 0.03 \%$ of added $\mathrm{T}_{4} / \mu \mathrm{g}$ protein per $\mathrm{h}$ (mean \pm SE, $n=18$ ) in the sham-controls. 1 and $2 \mathrm{~d}$ after thyroidectomy $T_{4}$ to $T_{3}$ conversion rates were increased to $183 \pm 31 \%$ of control $(n=6, P<0.05)$ and $247 \pm 32 \%$ of control $(n=12, P<0.01)$, respectively. Likewise, PTU-insensitive $\mathrm{rT}_{3} 5^{\prime}$-deiodination was elevated to 263 and $221 \%$ of control 24 and $48 \mathrm{~h}$ after thyroidectomy, though the value at $24 \mathrm{~h}$ was not significantly higher than in controls $(0.1>P>0.05$ by Dunnett's test). The increments in $\mathrm{T}_{4} 5^{\prime}$-deiodination and PTU-insensitive $\mathrm{rT}_{3} 5^{\prime}$-deiodination at $2 \mathrm{~d}$ were prevented by the administration of replacement doses of $T_{4}(0.8 \mu \mathrm{g} / 100 \mathrm{~g}$ body wt per $\mathrm{d})$ or $\mathrm{T}_{3}(200 \mathrm{ng} / 100$ $\mathrm{g}$ body $\mathrm{wt} / \mathrm{twice}$ daily) to the thyroidectomized rats. Injection of sham-controls with the same quantity of $T_{3}$ did not affect pituitary $T_{4} 5^{\prime}$-deiodinase activity. None of these treatments significantly altered $\mathrm{rT}_{3} 5^{\prime}$ deiodination measured in the absence of PTU.

In rats thyroidectomized $12-18 \mathrm{~d}$ previously, mean $\mathrm{T}_{3}$ production from $10 \mathrm{nM} \mathrm{T} \mathrm{T}_{4}$ decreased as early as 4 $\mathrm{h}$ after injection of 20 and $200 \mu \mathrm{g} \mathrm{T} / 100 \mathrm{~g}$ body wt to 29 and $1 \%$ of the hypothyroid control value, respectively (Table III). PTU-insensitive $\mathrm{rT}_{3} 5^{\prime}$-deiodination by pituitary tissue from thyroidectomized rats was also significantly suppressed to $16 \%$ of hypothyroid control values $4 \mathrm{~h}$ after $200 \mu \mathrm{g} \mathrm{T}_{3} / 100 \mathrm{~g}$ body wt (Table III). Total $\mathrm{rT}_{3} 5^{\prime}$-deiodination was also significantly decreased $4 \mathrm{~h}$ after $200 \mu \mathrm{g} \mathrm{T}_{3}$, but the difference between total and PTU-insensitive $\mathrm{rT}_{3} 5^{\prime}$-deiodination was not significantly altered by this $\mathrm{T}_{3}$ dose: $33 \mathrm{fmol} \mathrm{I}^{-} / \mathrm{mg}$ protein per $\mathrm{h}$ in the hypothyroid controls vs. $40 \mathrm{fmol} \mathrm{I}^{-} / \mathrm{mg}$ protein per $\mathrm{h}$ in the $T_{3}$-treated animals.

\section{DISCUSSION}

The findings detailed above establish the presence of two pathways of iodothyronine $5^{\prime}$-deiodination in rat pituitary tissue, similar to the pathways we have described in rat brain $(27,28)$. Both pathways accept $r \mathrm{~T}_{3}$ as a substrate but $5^{\prime}$-deiodination of $\mathrm{T}_{\mathbf{4}}$, and inhibition of $\mathrm{rT}_{3} 5^{\prime}$-deiodination by $\mathrm{T}_{4}$, are only detectable via a PTU-insensitive pathway. 
TABLE II

Acute Effects of In Vivo Thyroid Hormone Depletion and Repletion on Pituitary Iodothyronine 5'-Deiodination

\begin{tabular}{|c|c|c|c|c|c|c|}
\hline \multirow{3}{*}{ Treatment } & & & \multicolumn{4}{|c|}{$\mathrm{rT}_{3} 5^{\prime}$-Deiodination } \\
\hline & \multicolumn{2}{|c|}{$T, 5^{\prime}$-deiodination } & \multicolumn{2}{|c|}{ Total } & \multicolumn{2}{|c|}{ PTU-insensitive } \\
\hline & $n$ & \% euthyroid & $n$ & \multicolumn{2}{|c|}{ \% euthyroid } & $\%$ total \\
\hline Euthyroid & 18 & $100 \pm 13$ & 10 & $100 \pm 12$ & $100 \pm 6$ & $16 \pm 1$ \\
\hline $24 \mathrm{~h}$ Tx & 6 & $183 \pm 31^{\circ}$ & 5 & $146 \pm 20$ & $263 \pm 56$ & $22 \pm 9$ \\
\hline $48 \mathrm{~h} \mathrm{Tx}$ & 12 & $247 \pm 32 \ddagger$ & 4 & $112 \pm 8$ & $221 \pm 21 \ddagger$ & $31 \pm 3 \ddagger$ \\
\hline $48 \mathrm{~h} \mathrm{Tx}+\mathrm{T}_{4}$ & 4 & $101 \pm 28$ & & N.D. & & \\
\hline $48 \mathrm{~h} \mathrm{Tx}+\mathrm{T}_{3}$ & 10 & $138 \pm 23$ & 3 & $117 \pm 10$ & $136 \pm 29$ & $18 \pm 4$ \\
\hline Euthyroid $+T_{3}$ & 8 & $110 \pm 15$ & 4 & $138 \pm 21$ & $129 \pm 21$ & $15 \pm 2$ \\
\hline
\end{tabular}

Results are mean \pm SEM. Euthyroid rats were sham thyroidectomized. $T_{4}$ treatment was $800 \mathrm{ng}$ per $100 \mathrm{~g}$ body wt s.c. 8 and $32 \mathrm{~h}$ after thyroidectomy. $\mathrm{T}_{3}$ treatment was 200 ng per $100 \mathrm{~g}$ body wt s.c. $8,14,32$, and $40 \mathrm{~h}$ after thyroidectomy. Rats were killed $48 \mathrm{~h}$ after sham operation or thyroidectomy, except the 24-h Tx group, which were killed $24 \mathrm{~h}$ after thyroidectomy. $\mathrm{rT}_{3} 5^{\prime}$-deiodination was measured at $2 \mathrm{nM} \mathrm{rT}_{3}$ and $20 \mathrm{mM}$ DTT, with $\mathrm{I}^{-}$release quantitated by assay $\mathrm{A}$. To measure PTU-insensitive activity, 1 $\mathrm{mM}$ PTU was added to the incubations. $\mathrm{T}_{4} 5^{\prime}$-deiodination was measured at $0.2 \mathrm{nM} \mathrm{T}$ and $100 \mathrm{mM}$ DDT, with reaction products quantitated by assay $\mathrm{B}$. Tx, thyroidectomized rats, ND, rates were not determined. ${ }^{\circ} P<0.05$ compared with euthyroid rats. $\ddagger P$ $<0.01$. There was no significant difference between the 24- and 48-h sham-operated controls; therefore their results were pooled.

The PTU-sensitive pathway in pituitary, like PTUsensitive iodothyronine $5^{\prime}$-deiodination in the cerebral cortex, is similar to the iodothyronine $5^{\prime}$-deiodinase activity in rat liver and kidney $(25,26)$. As in kidney, liver, and rat brain, deiodination follows ping-pong type kinetics with DTT as cosubstrate, and inhibition of this pathway by PTU is noncompetitive with respect to $\mathrm{rT}_{3}$ but competitive with respect to DTT (Fig. 1). In cerebral cortex and kidney, this pathway is also inactivated by extremely low $(1 \mu \mathrm{M})$ concentrations of iodoacetate, a sulfhydryl active reagent $(26,28)$. This evidence suggests the participation of a highly reactive sulfhydryl group in the reductive removal of the 5 '-iodine, and, further, that the reaction mechanism comprises two half reactions: $\mathrm{E}-\mathrm{SH}+\mathrm{rT}_{3} \rightarrow$ $\mathrm{E}-\mathrm{SI}+3,3^{\prime}-\mathrm{T}_{2} ; \mathrm{E}-\mathrm{SI}+\mathrm{DTT}_{\text {reduced }} \rightarrow \mathrm{E}-\mathrm{SH}+\mathrm{DTT}_{\text {oxidized }}$ $+\mathrm{HI}$.

As in the brain $(27,28)$, this PTU-sensitive pathway

TABLE III

Acute Effects of Supraphysiological Doses of $T_{3}$ on Pituitary Iodothyronine 5'-Deiodination

\begin{tabular}{|c|c|c|c|c|c|c|}
\hline \multirow{3}{*}{ Treatment } & & & \multicolumn{4}{|c|}{$\mathrm{rT}_{3} 5^{\prime}$-Deiodination } \\
\hline & \multicolumn{2}{|c|}{ T, 5'-Deiodination } & \multicolumn{2}{|r|}{ Total } & \multicolumn{2}{|c|}{ PTU-insensitive } \\
\hline & $n$ & $\begin{array}{l}\text { \% hypothyroid } \\
\text { control }\end{array}$ & $n$ & \multicolumn{2}{|c|}{$\begin{array}{l}\text { \% hypothyroid } \\
\text { control }\end{array}$} & $\%$ total \\
\hline $\begin{array}{l}\text { Hypothyroid control } \\
\text { Hypothyroid }\end{array}$ & 9 & $100 \pm 10$ & 6 & $100 \pm 9$ & $100 \pm 12$ & $64 \pm 8$ \\
\hline $\begin{array}{l}+20 \mu \mathrm{g} \mathrm{T}_{3}, 4 \mathrm{~h} \\
\text { Hypothyroid }\end{array}$ & 6 & $29 \pm 4^{\circ}$ & & N.D. & & \\
\hline$+200 \mu \mathrm{g} \mathrm{T}_{3}, 4 \mathrm{~h}$ & 11 & $1 \pm 0.3^{\circ}$ & 5 & $54 \pm 12 \ddagger$ & $16 \pm 3^{\circ}$ & $10 \pm 2^{\circ}$ \\
\hline
\end{tabular}

Rats were thyroidectomized $18-21 \mathrm{~d}$ before study. $\mathrm{T}_{3}$ or vehicle was injected into the jugular vein under light ether anesthesia $4 \mathrm{~h}$ prior to death. Values are mean \pm SEM Reaction conditions are as given in Table II. $\bullet P<0.01$. ND, not determined. $\downarrow P$ $<0.05$ vs. hypothyroid control. 
of in vitro $\mathrm{rT}_{3} 5^{\prime}$-deiodination prevails in pituitary tissue from euthyroid rats, even at substrate concentrations well below the $K_{\mathrm{m}}$ for $\mathrm{rT}_{3}$, owing to the high $V_{\max }$ compared to that of the PTU-insensitive pathway. The substrate specificity of the PTU-sensitive pathway in pituitary is not entirely clear. Under our experimental conditions, $5^{\prime}$-deiodination of $\mathbf{T}_{4}$ via this pathway was not detectable, nor was deiodination of $2 \mathrm{nM} \mathrm{rT}_{3}$ inhibited by $100 \mathrm{nM} \mathrm{T}_{4}$ (Fig. 2). However, in light of the difference between tissues in $\mathrm{rT}_{3} 5^{\prime}$-deiodination rates, these would be expected findings if $V_{\max } / K_{m}$ ratios for PTU-sensitive 5'-deiodination of $\mathrm{rT}_{3}$, and $\mathrm{T}_{4}$ were similar in pituitary as in liver and kidney $(25,26)$.

The PTU-insensitive 5'-deiodinating pathway in the pituitary is similar to that we have recently identified in rat cerebral cortex $(27,28)$. The apparent $K_{\mathrm{m}}$ for $\mathrm{T}_{4}$ and $\mathrm{rT}_{3}$ are similar in both tissues, $<5 \mathrm{nM}$. Each of these iodothyronines is a competitive inhibitor of 5 -deiodination of the other, with similar apparent $K_{\mathrm{m}}$ and $K_{\mathrm{i}}: 0.6-0.9 \mathrm{nM}$ and $1.3 \mathrm{nM}$ for $\mathrm{T}_{4}$, and 2.9 and $1.7 \mathrm{nM}$ for $\mathrm{rT}_{3}$ in pituitary microsomes. as detailed above. In cerebral cortex, this pathway is not affected by PTU or $100 \mu \mathrm{M}$ iodoacetate, and the reaction follows sequential type kinetics as the DTT concentration is varied $(27,28)$, findings similar to those in pituitary microsomes (Fig. 4). This kinetic pattern suggests that both the iodothyronine and the thiol combine with the enzyme before the reaction takes place, and that the iodine removed from the iodothyronine is not transferred to an enzyme sulfur, but rather, perhaps, to the cofactor $-\mathrm{SH}$ group: $\mathrm{E}+\mathrm{T}_{4}+\mathrm{DTT}_{\text {reduced }} \rightarrow$ $\mathrm{E}-\mathrm{T}_{4}$-DTT $\rightarrow \rightarrow \mathrm{E}+\mathrm{T}_{3}+\mathrm{DTT}_{\text {oxidized }}+\mathrm{HI}$. Other more complex, reaction mechanisms are also possible (34).

As in brain tissue $(27,28)$, the PTU-insensitive pathway of $\mathrm{rT}_{3} 5^{\prime}$-deiodination predominates in microsomes from hypothyroid rats when the $\mathrm{rT}_{3}$ concentration is $2 \mathrm{nM}$. This is due both to an increase in the activity of the PTU-insensitive pathway and a decrease in the activity of the PTU-sensitive pathway. However, because the $V_{\max }$ of the PTU-sensitive pathway is severalfold higher than that of the PTU insensitive pathway (even in hypothyroid tissue), an increase of the $\mathrm{rT}_{3}$ concentration in the assay to $\simeq 10 \mathrm{nM}$ or higher would make the PTU-insensitive pathway difficult to detect.

The relationship between the two pathways of $5^{\prime}$ deiodination in pituitary and brain is unclear. Possibly, they represent two different enzymes. If so, the similarities in the properties of the PTU-sensitive pathway in pituitary, brain, liver, and kidney suggest the possibility that a single enzyme is present in all of these tissues, with $\sim 40$-fold higher concentrations in pituitary than in cerebrocortical microsomes, and 1,000- 2,000-fold more in liver and kidney microsomes than in pituitary (25-28). Another possibility is that the two 5 -deiodination pathways correspond to different forms of the same enzyme. This possibility is suggested by the similarity in subcellular distribution of the two activities in brain tissue (35). Purification of the deiodinating activities will be necessary to distinguish between these possibilities.

In vivo administration of PTU has no effect on in vivo intrapituitary conversion of $T_{4}$ to $T_{3}(8)$, as is true also for cerebral cortex and cerebellum (36). Likewise, PTU has no effect on $\mathrm{T}_{4} 5^{\prime}$-deiodination by pituitary tissue in vitro $[(12,17)$ and present results]. In contrast 5 -deiodination of $\mathrm{rT}_{3}$ by pituitary tissue in vitro is inhibited by pretreatment of rats in vivo with PTU (36). It therefore appears that the PTU-insensitive $5^{\prime}$ deiodinating pathway is responsible for all of the locally produced $T_{3}$ in rat pituitary, which amounts to $>50 \%$ of the $\mathrm{T}_{3}$ in that tissue. This is in marked contrast to the inhibitory effect of PTU on $\mathrm{T}_{4}$ to $\mathrm{T}_{3}$ conversion in liver and kidney (18-20). The physiological significance of the PTU-sensitive 5'-deiodination pathway in the pituitary or brain, is not yet known. If it is an altered form of the PTU-insensitive enzyme, it could serve as a reservoir of latent enzyme, available for transformation into PTU-insensitive activity, which could then produce $T_{3}$.

We previously reported increases in pituitary $T_{4} 5^{\prime}$ deiodinase activities in chronically hypothyroid rats $(11,12)$, recently confirmed by Maeda and Ingbar (13). They observed an increase in $\mathrm{T}_{4} 5^{\prime}$-deiodination by rat hemipituitaries by $24 \mathrm{~h}$ (but not 4-6 h) after thyroidectomy, with further increases at 7 and $14 \mathrm{~d}$. We have reported such a rapid increase for cerebral cortex 5 -deiodinase after thyroidectomy (29). Our present results for the time course of the increase of PTUinsensitive $\mathrm{rT}_{3} 5^{\prime}$-deiodination and $\mathrm{T}_{4} 5^{\prime}$-deiodination in pituitary tissue are similar (Fig. 5 and Table II). In addition, we found that the increase in activity is selective for the PTU-insensitive process: the PTU-sensitive activity showed a gradual decrease after thyroidectomy, like that observed for hepatic iodothyronine $5^{\prime}$-deiodination $(13,29)$. We have also noted decreases in pituitary $\mathrm{T}_{4} 5^{\prime}$-deiodination in thyroid hormone-treated rats $(11,12)$. Maeda and Ingbar found a decrease of $\sim 50 \%$ in $\mathrm{T}_{4} 5^{\prime}$-deiodination $4 \mathrm{~h}$ after treatment of hypothyroid rats with $1.5 \mu \mathrm{g} / \mathrm{T}_{3}$ per $100 \mathrm{~g}$ body wt (13). Though assay methods were not identical, comparison of their results with those in Table III suggest that the higher $T_{3}$ doses used here caused an even greater reduction in PTU-insensitive 5 -deiodination, and that an effect of $T_{3}$ treatment might well be demonstrable after shorter time intervals. If so, the reduction in PTU-insensitive $5^{\prime}$-deiodination may be as rapid a response to $T_{3}$ as is inhi- 
bition of thyrotropin release, which can be demonstrated by $\mathrm{l} \mathrm{h}$ after $\mathrm{T}_{3}$ or $\mathrm{T}_{4}(37)$. Physiological replacement doses of either $T_{4}$ or $T_{3}$ prevented the increase in PTU-insensitive 5'-deiodination $48 \mathrm{~h}$ after thyroidectomy (Table II), suggesting that control of this enzyme activity is not a unique property of the $\mathrm{T}_{4}$ molecule itself

In conclusion, we have demonstrated two pathways for the $5^{\prime}$-deiodination of iodothyronines in rat pituitary. The processes differ with respect to substrate specificity, susceptibility to PTU-inactivation and reaction kinetics, probably reflecting distinct enzyme entities with different catalytic mechanisms. Moreover, opposite changes in these two enzyme activities are observed in this tissue in response to thyroid hormone depletion and repletion. It is conceivable that these compensatory changes prevent large fluctuations in intracellular $\mathrm{T}_{3}$, and thereby $\mathrm{GH}$ secretion rates, in the face of variations in plasma thyroid hormone concentrations. The benefits of such a mechanism in the regulation of thyrotroph function, however, is less clear, or even doubtful, inasmuch as it would appear to interfere with the optimal negative feedback control of TSH secretion. The possible association of the PTUinsensitive 5 '-deiodinase with specific cell populations in the anterior pituitary and the mechanism of regulation of these enzyme activities by thyroid hormone, are important subjects for future investigations.

\section{ACKNOWLEDGMENTS}

We thank Jeffrey Tatro, Sarah Mellen, Kimberlee Yaskoski, and Joe Woods for expert technical assistance, and Faith Baldwin for help in manuscript preparation.

This work was supported in part by a grant to Dr. Visser from the Netherlands Organization for the Advancement of Pure Research, by National Institutes of Health grants AM 18616 and AM 25340, Biomedical Research Support grant S07-RR05489 from National Institutes of Health Division of Research Support Services, a grant from the William F. Milton Fund, National Institutes of Health Research Career Development Award AM 00727 Dr. Kaplan, and National Institutes of Health New Investigator Award AM 30309 to Dr. Leonard.

\section{REFERENCES}

1. Hervas, F., G. Morreale de Escobar, and F. Escobar del Rey. 1975. Rapid effects of single small doses of $L$-thyroxine and triiodo-L-thyronine on growth hormone, as studied in the rat by radioimmunoassay. Endocrinology. 97: 91-98

2. Ivarie, R. D., J. D. Baxter, and J. A. Morris. 1981. Interaction of thyroid and glucocorticoid hormones in rat pituitary tumor cells; specificity and diversity of the responses analyzed by two-dimensional gel electrophoresis. J. Biol. Chem. 256: 4520-4524

3. Oppenheimer, J. H., and W. Dillmann. 1978. Nuclear receptors for triiodothyronine: a physiological perspec- tive. In Receptors and Hormone Action. L. Birnbaumer and B. W. O’Malley, editors. Vol. III. Academic Press, Inc., New York. pp. 1-33.

4. Samuels, H. H. 1978. In vitro studies on thyroid hormone receptors. In Receptors and Hormone Action. L. Birnbaumer and B. W. O’Malley, editors. Vol. III. Academic Press, Inc., New York. pp. 35-74.

5. Latham, K. R., K. M. McLeod, S. S. Papavasiliou, J. A Martial, P. H. Seeburg, H. M. Goodman, and J. D. Baxter. 1978. Regulation of gene expression by thyroid hormones. In Receptors and Hormone Action. L. Birnbaumer and B. W. O'Malley, editors. Vol. III. Academic Press, Inc., New York, pp. 75-100

6. Seo, H., G. Vassart, H. Brocas, and S. Refetoff. 1977 Triiodothyronine stimulates specifically growth hormone mR.NA in rat pituitary tumor cells. Proc. Natl. Acad. Sci. USA. 74: 2054-2058.

7. Larsen, P. R., J. E. Silva, and M. M. Kaplan. 1981. Relationships between circulating and intracellular thyroid hormones: physiological and clinical implications. Endocrine Rev. 2: 87-102.

8. Silva, J. E., and P. R. Larsen. 1978. Contributions of plasma triiodothyronine and local thyroxine monodeiodination to triiodothyronine and nuclear triiodothyronine receptor saturation in pituitary, liver, and kidney of hypothyroid rats. Further evidence relating saturation of pituitary nuclear triiodothyronine receptors and the acute inhibition of thyroid-stimulating hormone release. J. Clin. Invest. 61: 1247-1259.

9. Silva, J. E., T. E. Dick, and P. R. Larsen. 1978. The contribution of local tissue thyroxine monodeiodination to the nuclear $3,5,3^{\prime}$-triiodothyronine in pituitary liver and kidney of euthyroid rats. Endocrinology. 103: 11961207

10. Silva, J. E., M. M. Kaplan, R. G. Cheron, T. E. Dick, and P. R. Larsen. 1978. Thyroxine to 3,5,3'-triiodothyronine conversion by rat anterior pituitary and liver. Metab. Clin. Exp. 27: 1601-1607

11. Cheron, R. G., M. M. Kaplan, and P. R. Larsen. 1979 Physiological and pharmacological influences on thyroxine to $3,5,3^{\prime}$-triiodothyronine conversion and nuclear $3,5,3^{\prime}$-triiodothyronine binding in rat anterior pituitary. J. Clin. Invest. 64: 1402-1414.

12. Kaplan, M. M. 1980. Thyroxine 5 '-monodeiodination in rat anterior pituitary homogenate. Endocrinology. 106: $567-576$

13. Maeda, M., and S. H. Ingbar. 1982. Effect of alterations in thyroid status on the metabolism of thyroxine and triiodothyronine by rat pituitary gland in vitro. J. Clin. Invest. 69: 799-808

14. El-Zaheri, M. M., L. E. Braverman, and A. G. Vagenakis 1980. Enhanced conversion of thyroxine to triiodothyronine by the neonatal rat pituitary. Endocrinology. 106: 1735-39.

15. Kumara-Siri, M. H., K. Lee, and M. I. Surks. 1981. Regulation of thyrotropin secretion in rats bearing the Walker 256 carcinoma. Endocrinology. 109: 1760-1768

16. Melmed, S., A. Kurtzman, A. Reed, and J. M. Hershman 1979. Non-thyrotropic pituitary cells in culture convert T4 to T3. Life Sci. 24: 1947-1952.

17. Melmed, S., M. Nelson, N. Kaplowitz, T. Yamada, and Y. Hershman. 1981. Glutathione-dependent thyroxine 5 '-monodeiodination modulates growth hormone production by cultured nonthyrotropic rat pituitary cells. Endocrinology. 108: 970-976.

18. Visser, T. J., I. Van der Does-Tobe, R. Doctor, and G Hennemann. 1975. Conversion of thyroxine into triio- 
dothyronine by rat liver homogenate. Biochem. J. 150: 489-493.

19. Leonard, J. L., and I. N. Rosenberg. 1978. Thyroxine 5 -deiodinase activity of rat kidney: Observations on activation by thiols and inhibition by propylthiouracil. Endocrinology. 103: 2137-2144.

20. Kaplan, M. M., and R. D. Utiger. 1978. Iodothyronine metabolism in liver and kidney homogenates from hyperthyroid and hypothyroid rats. Endocrinology. 103: 156-161

21. Kaplan, M. M., and K. A. Yaskoski. 1980. Phenolic and tyrosyl ring deiodination of iodothyronines in rat brain homogenates. J. Clin. Invest. 66: 551-562.

22. Crantz, F. R., and P. R. Larsen. 1980. Rapid thyroxine to 3,5,3'-triiodothyronine conversion and nuclear $3,5,3^{\prime}$ triiodothyronine binding in rat cerebral cortex and cerebellum. J. Clin. Invest. 65: 935-938.

23. Larsen, P. R., T. E. Dick, M. M. Markovitz, M. M. Kaplan, and T. G. Gard. 1979. Inhibition of intrapituitary thyroxine to $3,5,3^{\prime}$-triiodothyronine conversion prevents the acute suppression of thyrotropin release by thyroxine in hypothyroid rats. J. Clin. Invest. 64: 117-128.

24. Obregon, M. J., A. Pascual, J. Mallol, G. Morreale de Escobar, and F. Escobar del Rey. 1980. Evidence against a major role of $L$-thyroxine at the pituitary level: Studies in rats treated with iopanoic acid (Telepaque). Endocrinology. 106: 1827-36.

25. Visser, T. J., D. Fekkes, R. Docter, and G. Hennemann. 1979. Kinetics of enzymic reductive deiodination of iodothyronines; effect of pH. Biochem. J. 179: 489-495.

26. Leonard, J. L., and I. N. Rosenberg. 1980. Thyroxine 5 -deiodinase from rat kidney. Iodothyronine substrate specificity and the $5^{\prime}$-deiodination of reverse triiodothyronine. Endocrinology. 107: 1376-1383.

27. Visser, T. J., J. L. Leonard, M. M. Kaplan, and P. R. Larsen. 1981. Different pathways of iodothyronine 5'- deiodination in rat cerebral cortex. Biochem. Biophys. Res. Commun. 101: 1297-1304.

28. Visser, T. J., J. L. Leonard, M. M. Kaplan, and P. R Larsen. 1982. Kinetic evidence suggesting two mechanisms for iodothyronine $5^{\prime}$-deiodination in rat cerebral cortex. Proc. Nat. Acad. Sci. USA. 79: 5080-5084.

29. Leonard, J. L., M. M. Kaplan, T. J. Visser, J. E. Silva, and P. R. Larsen. 1981. Cerebral cortex responds rapidly to thyroid hormones. Science (Wash DC). 214: 571-573.

30. Weeke, J., and H. Orskov. 1973. Synthesis of monolabeled 3,5,3'-triiodothyronine and thyroxine of maximum specific activity for radioimmunoassay. Scand. J. Clin. Lab. Invest. 32: 357-360.

31. Bradford, M. M. 1976. A rapid and sensitive method for the quantitation of microgram quantities of protein utilizing the principle of protein-dye binding. Anal. Biochem. 72: 248-254.

32. Zar, J. 1974. Biostatistical analysis. Prentice-Hall, Inc., Englewood Cliffs, NJ.

33. Rosenthal, H. E. 1967. A graphic method for the determination and presentation of binding parameters in a complex system. Anal. Biochem. 20: 525-532.

34. Segel, I. 1975. Enzyme kinetics: behavior and analysis of rapid equilibrium and steady state enzyme systems. Wiley-Interscience, New York.

35. Leonard, J. L., H. Rennke, M. M. Kaplan, and P. R. Larsen. 1982. Subcellular distribution of iodothyronine 5 '-deiodinase in cerebral cortex from hypothyroid rats. Biochim. Biophys. Acta. 718: 109-119.

36. Silva, J. E., J. L. Leonard, F. R. Crantz, and P. R. Larsen. 1982. Evidence for two tissue specifics pathways for in vivo thyroxine $5^{\prime}$-deiodination in the rat. J. Clin. Invest. 69: 1176-1184.

37. Silva, J. E., and P. R. Larsen. 1978. Peripheral metabolism of homologous thyrotropin in euthyroid and hypothyroid rats: acute effects of thyrotropin-releasing hormone, triiodothyronine, and thyroxine. Endocrinology. 102: 1783-1796. 